\title{
Molecular and morphological identification of Cortinarius eucaeruleus Rob. Henry (subgenus Phlegmacium) from Türkiye
}

\author{
Meryem Şenay ŞENGÜL DEMIRAK ${ }^{\mathbf{1}^{*}}{ }^{\circ}$, Hakan IŞIK ${ }^{2}$, İbrahim TÜRKEKUL ${ }^{3}$ \\ ${ }^{1}$ Tokat Gaziosmanpasa University, Science and Arts Faculty, Department of Molecular Biology and Genetics, \\ Tokat, Türkiye \\ ${ }^{2}$ Tokat M. Emin Sarac Anatolian Religious High School, Tokat, Türkiye \\ ${ }^{3}$ Tokat Gaziosmanpasa University, Science and Arts Faculty, Department of Biology, Tokat, Türkiye \\ *senay.sengul@gop.edu.tr, ${ }^{2}$ hakanbiyoloji@gmail.com, ${ }^{3}$ ibrahim.turkekul@gop.edu.tr
}

Received : 30.12 .2021

Accepted : 22.01.2022

Online $\quad: 25.01 .2022$

\section{Türkiye'den Cortinarius eucaeruleus Rob. Henry (subgenus Phlegmacium)'un moleküler ve morfolojik belirlenmesi}

\begin{abstract}
Cortinarius eucaeruleus is identified from central Black Sea region of Türkiye based on morphological characteristics and ribosomal DNA gene sequence analyses. This species was found on calcareous soil associated with Quercus in autumn season from Tokat province in Türkiye. It has distinctive morphological features such as strong and deep violaceous blue pileus, ellipsoid and densely verrucose spores. In addition to the morphological features, the ITS (internal transcribed spacer) and LSU (large subunit ribosomal) sequence analyses indicated that the studied specimen is C. eucaeruleus that is identified for the first time from Türkiye.
\end{abstract}

Key words: Cortinariaceae, molecular taxonomy, ITS, LSU, Turkiye

Özet: Cortinarius eucaeruleus, Türkiye'nin Orta Karadeniz bölgesinden morfolojik özellikler ve ribozomal DNA gen dizi analizlerine dayalı olarak tanımlanmıştır. Bu tür, Türkiye'de Tokat ilinden sonbahar mevsiminde Quercus ile ilişkili kalkerli topraklarda bulunmuştur. Güçlü ve derin morumsu mavi tüy, elipsoid ve yoğun verrukoz sporları gibi ayırt edici morfolojik özelliklere sahiptir. Morfolojik özelliklere ek olarak, ITS (internal transcribed spacer) ve LSU (large subunit) ribosomal dizi analizleri, incelenen örneğin Türkiye'den ilk kez teşhis edilen C. eucaeruleus olduğunu göstermiștir.

Anahtar Kelimeler: Cortinariaceae, moleküler taksonomi, ITS, LSU, Türkiye

Citation: Şengül Demirak MŞ, Iş̧k H, Türkekul İ (2022). Molecular and morphological identification of Cortinarius eucaeruleus Rob.

Henry (subgenus Phlegmacium) from Türkiye. Anatolian Journal of Botany 6(1): 27-33.

\section{Introduction}

Cortinarius (Pers.) Gray is the most diverse and speciesrich genus of macrofungi and contains a complex taxonomic system including several subgenera, sections and other infrageneric taxa (Kirk et al., 2008). It is divided into five to nine subgenera based upon micromorphology (Moser and Horak, 1975). Among them, subgenus Phlegmacium, subgenus Telamonia and subgenus Dermocybe are the most diverse of the subgenera. In general, the macrofungi species in subg. Phlegmacium are ectomycorrhizal fungi associated with deciduous and coniferous trees and usually have a vivid colored basidiocarp (Garnica et al., 2003). They are nonhygrophanous and have a dry stipe and viscous or sticky pileus surface in moist conditions (Soop et al., 2019). This subgenus is divided into the sections and other infrageneric groups, primarily based on gill color, and then veil color, pileus color, odor and the color change that occurs with alkaline chemicals (Moser, 1983; Garnica et al., 2003). Some species in this subgenus are widely distributed, while others may show limited distribution due to host specificity, the climate and soil requirements (Garnica et al., 2003; Liimatainen et al., 2014; Soop, 2014).

More than 5000 records in Cortinarius genus have been published worldwide (Index fungorum, CABI Bioscience Databases). However, many species identified as Cortinarius have been shown to be synonyms (Moser and
Horak, 1975; Moser, 1983; Breitenbach and Kränzlin, 2000; Kirk, 2011; Liimatainen et al., 2014; Brandrud et al., 2018; Soop et al., 2019). Thus, morphology-based taxonomic studies in this genus are yet to be informative and phylogenetic tools need to be undertaken for clarification within the genus. The phylogenetic relationship of the Cortinarius species is inferred from gene regions encoding nuclear ribosomal internal transcribed spacer (ITS), nuclear large subunit ribosomal DNA (nLSU), and the two largest subunits of RNA polymerase II (RPB1 and RPB2), and an increasing number of studies are being conducted to understand species delimitation and identification based on sequence analysis. Although some subgenera are supported as monophyletic, subg. Phlegmacium is shown to be polyphyletic (Høiland and Holst-Jensen, 2000; Peintner et al., 2004; Garnica et al., 2005).

Cortinarius eucaeruleus Rob. Henry is a macrofungi species grouped in the Subgenus Phlegmacium, section Caerulescentes Rob. Henry ex Moenne-Locc. \& Reumaux, clade Eucaerulei (Soop et al., 2019). Section Caerulescentes develops especially in calcareous soils. The pileus can be blue, lilac-violet, silver-gray, blue-gray and wine-brown. Lamella are violaceous at first, then becoming violaceous gray. There is distinctly a margin bulb on the stem. Its flesh does not react with alkaline chemicals or gives a brownish color (Moser, 1983; Soop, 2014). The 
clade Eucaerulei comprises species with medium-sized basidiomata that are pileocarpic with violaceous hues and found on calcareous soil with Quercus, Pinus and deciduous trees. This clade contains species such as $C$. caerulescentium, $C$. perpallens, $C$. eucaeruleus and $C$. terpsichores that are mostly distributed in Europe (Soop et al., 2019). C. eucaeruleus and C. terpsichores are the two species that are morphologically the most similar and could be synonymous (Tortelli, 2011; Ślusarczyk et al., 2015). However, sequence data separates them as two very closely related but morphologically different species (Soop et al., 2019).

In Türkiye, more than 130 Cortinarius species have been identified (Sesli et al., 2020). Here, we present the first report of Cortinarius eucaeruleus from Türkiye based on morphological, ecological and phylogenetical data. We provide sequence information for the two gene loci (nrITS and nrLSU) for better resolution of the sect. Phlegmacium species.

\section{Material and Method}

\subsection{Collection and morphological analyses}

The fresh basidiomata specimens belonging to the genus Cortinarius were collected from Yaylacik Mountain (Tokat) during field trips in autumn 2019. The specimens were photographed at their natural habitats and the macroscopic and ecological characteristics were recorded. They were wrapped in paper and placed in a box during laboratory transfer. A mature sample was selected to obtain a spore print of the sample. The samples were dried and the fungarium number was given. Microscopic studies were carried out on dry samples under a Nikon brand research microscope. Some chemicals (such as $5 \% \mathrm{KOH}, \mathrm{NaOH}$, Congo red) were used to rehydrate and dye dry samples during the studies. Basidiospore measurements were done, where $\mathrm{L}_{\mathrm{m}}$ is the average length, $\mathrm{W}_{\mathrm{m}}$ is the average width, $\mathrm{Q}$ is the quotient of length/width, and $\mathrm{Q}_{\mathrm{m}}$ is the average of all calculated $Q$ values for all basidiospores measured. At least 30 measurements of basidiospores were made from a single basidioma in profile view and basidiospore shape was described according to Bas (1969). Authors of fungal names are cited according to the IndexFungorum (http://www.indexfungorum.org) and MycoBank (http://www.mycobank.org). The findings obtained as a result of all these studies were compared with the existing literature (Knudsen and Vesterholt, 2008; Soop, 2014; Ślusarczyk et al., 2015; Muñoz Sánchez, 2018; Tanchaud, 2020a,b) to identify the studied fungal samples. Dried mushroom samples were stored in the fungarium of Tokat Gaziosmanpaşa University, Department of Biology (GOPUF).

\subsection{Molecular analyses}

\subsubsection{DNA extraction and PCR}

Genomic DNA was isolated from about $20 \mathrm{mg}$ of lamella materials of the sample using GeneMATRIX Plant \& Fungi DNA purification kit (EURx, Poland) following manufacturer's protocol. Approximately $700 \mathrm{bp}$ genomic sequence of the ITS1-5.8S-ITS2 region of the rDNA gene was amplified using primer pairs ITS4-ITS5 (White et al., 1990) and a 950 bp genomic sequence of the 28S LSU gene region was amplified using primer pairs LROR-LR5 (Vilgalys and Hester, 1990). Each gene amplification was performed in $30 \mu \mathrm{l}$ volume mixture containing $3 \mu \mathrm{l} 10 \mathrm{X}$ buffer, $3 \mu \mathrm{l}$ dNTP mix, $3 \mu$ degenerate primer pair (final concentration of $1 \mu \mathrm{M}$ each), $0.3 \mu$ Dream Taq DNA polymerase (Thermo), $10 \mu \mathrm{lgDNA}$ and $7.7 \mu \mathrm{l}$ sterile double distilled $\mathrm{H}_{2} \mathrm{O}\left(\mathrm{ddH}_{2} \mathrm{O}\right)$. Sterile $\mathrm{ddH}_{2} \mathrm{O}$ was also used for negative PCR control reactions instead of gDNA. PCR conditions for ITS amplification were set as follows: $5 \mathrm{~min}$ initial denaturation at $95{ }^{\circ} \mathrm{C}$ followed by 40 cycles of denaturation at $95{ }^{\circ} \mathrm{C}$ for $30 \mathrm{sec}$, annealing at $53{ }^{\circ} \mathrm{C}$ for 30 sec and extension at $72{ }^{\circ} \mathrm{C}$ for $1 \mathrm{~min}$ and a final extension for $10 \mathrm{~min}$. The conditions for LSU amplification included the same program except that the annealing temperature was set to $48^{\circ} \mathrm{C}$. Both PCR amplifications were verified by using $1 \%$ agarose gel electrophoresis. PCR products were sequenced from both ends using forward and reverse primers (BM Labosis Inc., Ankara).

\subsubsection{Sequence analysis and phylogenetics}

Sequences in both directions were checked for sequencing errors and an assembled sequence for both rDNA genomic regions was generated for further analysis. Basic Local Alignment Search Tool (BLAST) program from the National Center for Biotechnology Information (NCBI) nucleotide database was used for homology searches. Best matches from BLAST results of ITS and LSU analyses were retrieved from GenBank for phylogenetic analysis. Multiple sequence alignments were conducted using Clustal W (Larkin et al., 2007). Phylogenetic trees for each genomic region were generated using Molecular Evolutionary Genetics Analysis software (MEGA 7.0; Kumar et al., 2016). Phylogenetic analyses were inferred using the maximum likelihood (ML) and maximum parsimony (MP) methods. ML method was based on Tamura-Nei model (Tamura and Nei, 1993) with bootstrap support of 1000 replicates. Initial tree(s) for the heuristic search were automatically obtained by using NeighborJoining and BioNJ algorithms to a matrix of pairwise distances estimated using the Maximum Composite Likelihood (MCL) approach and topology with superior log likelihood value was selected. MP trees were constructed using the Tree-Bisection-Reconnection (TBR) search method with 100 random addition replications. The bootstrap support values > 50\% were marked on the branches of the tree. Hebeloma fastibile (Pers.) P. Kumm. was selected as an outgroup species.

\section{Results}

\subsection{Taxonomy}

Cortinarius eucaeruleus Rob. Henry, Docums Mycol. 20 (no. 77): 69 (1989) (Fig. 1)

\section{Mycobank MB 126119}

Pileus 40-100(120) mm diam., hemispherical to convex at first, later expanded, with involuted at first, then straight margin; very strong and deep violaceous blue, finely darklilac fibrillose. Lamellae crowded; narrowly adnate; violaceous at first, becoming violaceous gray, then finally rusty ochraceous; smooth to wavy at margin. Veil distinctly violaceous blue, sparse; cortina white with a violet tinge. Stipe 30-80 × 10-20 mm, cylindrical, central, stuffed, with a marginate bulb (up to $30 \mathrm{~mm}$ ), pale bluish white, soon white, yellowish when old. Flesh thick; firm; white to grayish white, often violaceous to violaceous gray in stem top when young, slightly flavescent in stipe-base. Smell and 

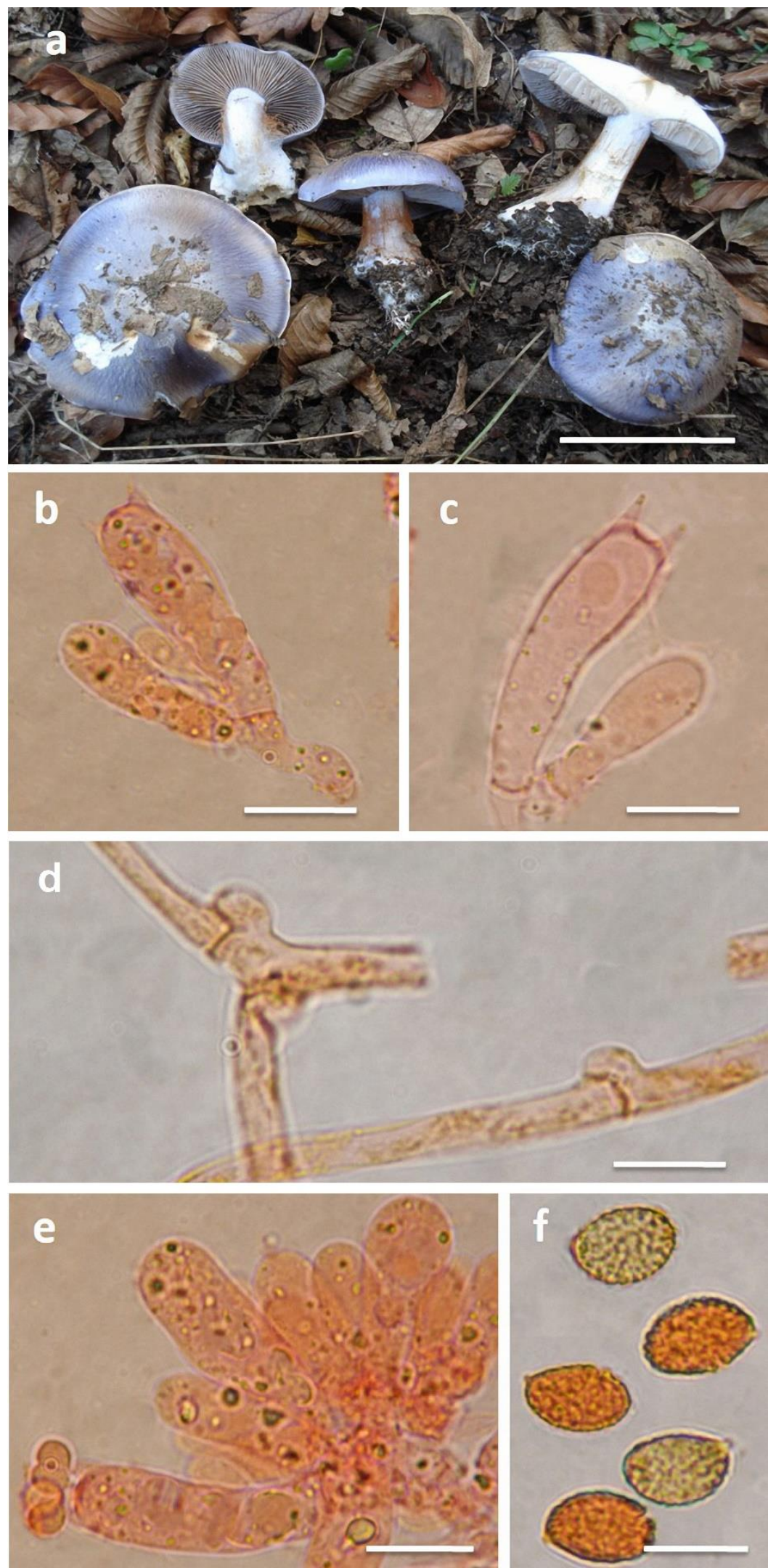

Figure 1. Cortinarius eucaeruleus (Collection HIS-20). a. Basidiomata in situ. b-c. basidia and basidioles. d. hyphae of pileipellis with clamp. e. basidia and basidioles. f. basidiospores. Scale bars: $a=80 \mathrm{~mm} ; \mathrm{b}-\mathrm{c}=10 \mu \mathrm{m}, \mathrm{d}-\mathrm{f}=10 \mu \mathrm{m}$.

taste somewhat Scleroderma-like; sweet flavor. Basidiospores 9-12.5(-13) $\times 5.5-7(-8) \mu \mathrm{m}, \mathrm{L}_{\mathrm{m}} \times \mathrm{W}_{\mathrm{m}}=11.8$ $\times 6.2 \mu \mathrm{m}, \mathrm{Q}=1.4-1.6(-1.8), \mathrm{Q}_{\mathrm{m}}=1.5$, elliptic to amygdaloid, distinctly and densely verrucose. Basidia 20 $25 \times 6-8 \mu \mathrm{m}$, cylindrical to clavate, with 4 sterigmata and a basal clamp. Cheilocystidia not seen. Pileipellis hyphae filamentous with terminal elements 7-9 $\times$ 4-5 $\mu \mathrm{m}$, cylindrical, septate. Clamp connections present on hyphae. Reactions of $\mathrm{NaOH}$ yellowish in flesh. 
Ecology and distribution: On calcareous soil in broad-leaf forests, among leaf litter under of members of the genera Carpinus L., Quercus L., Tilia L. and Corylus L., rarely with members of Fagus L. (Soop, 2014), fruiting in temperate periods between late October and early November, present at elevation below $1050 \mathrm{~m}$. Currently known from Tokat province Türkiye.

Specimen examined: TÜRKIYYE. Tokat Province: Akbelen village, among leaf litters in broad-leaf forests (especially present with Quercus) 1044 m., $40^{\circ} 28^{\prime} 00.57$ 'N- 36³8'47.98''E, 15 December 2019, HIS20.

\subsection{Molecular Phylogeny}

We determined the ITS and LSU genomic sequences of $C$. eucaeruleus sample from Türkiye, and both sequences were deposited at GenBank under the accession numbers MT116433 and MT116800, respectively. The identified ITS region included a 712 bp length of the ITS1-5.8S-ITS2 region and the amplified LSU region included a 976 bp long 28S LSU genomic segment. BLAST results for ITS region have given significant hits to previously known species, such as $C$. eucaeruleus and C. terpischores. A total of twenty-six sequence for ITS and twenty-three sequence for LSU phylogeny were retrieved from NCBI databases.

Phylogenetic trees based on ITS dataset were constructed using MP and ML methods and both methods have resulted in similar topologies. Thus, we used only ML tree to infer the evolutionary relationship of the newly identified species. Based on the ITS tree, the studied sample clustered in the $C$. eucaeruleus clade with strong support $(99 \% \mathrm{ML}$ bootstrap) (Fig. 2). Cortinarius terpischores (JF907894) and C. caerulescens (MH718791) also grouped within the same clade, which indicate that they are genetically close with $C$. eucaeruleus species. Since there were no previously identified LSU sequences for C. eucaeruleus from different collections, the LSU-based phylogenetic tree did not provide a good phylogenetic inference as the ITS tree. Only one representative for $C$. caerulescens and $C$. terpischores were used, and they formed a clade including $C$. eucaeruleus from this study (Fig. 3).

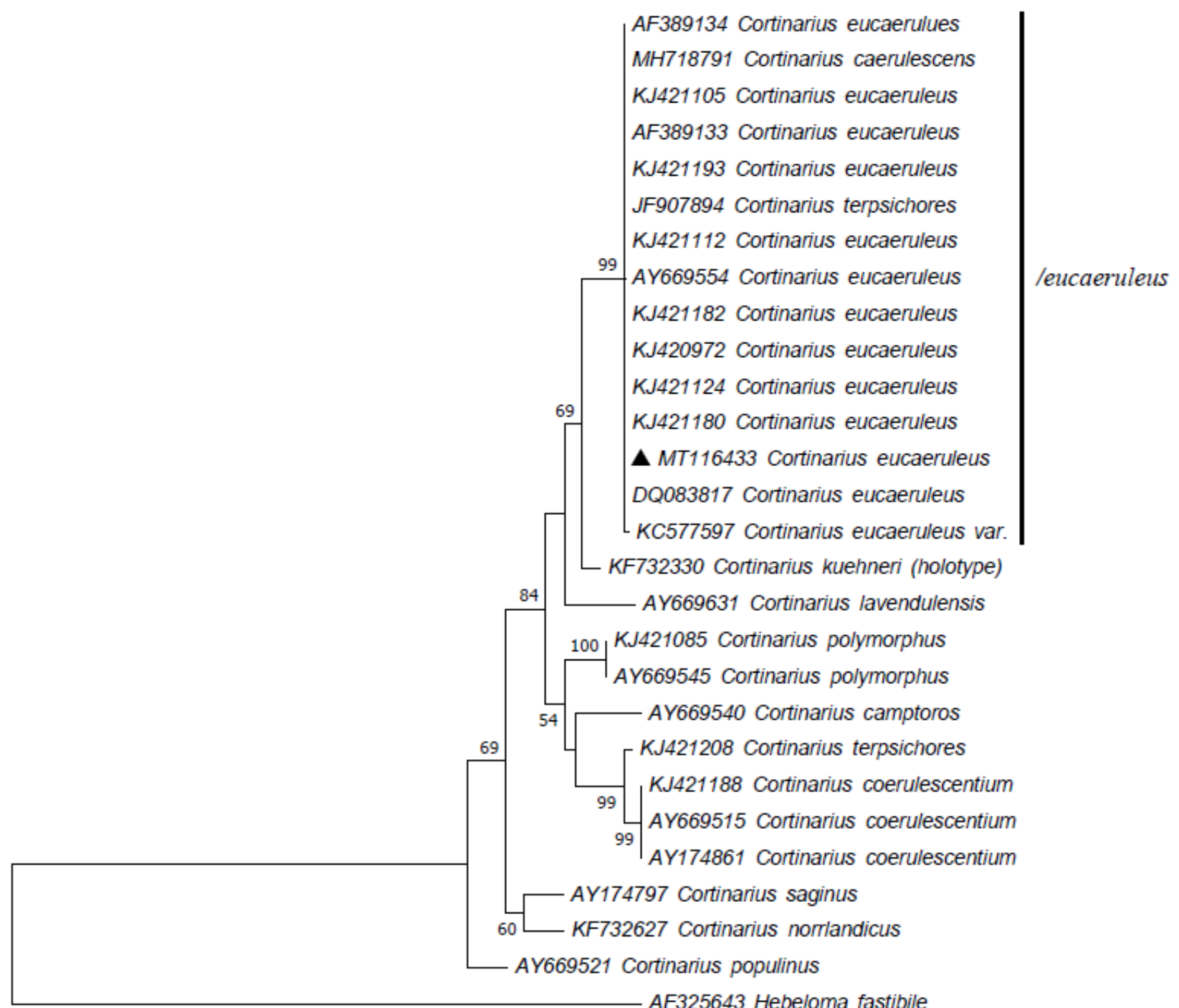

AF325643 Hebeloma fastibile

20

Figure 2. The ML phylogenetic tree of Cortinarius based on the ITS gene region. Black triangle indicates the identified species $C$. eucaeruleus in this study. Hebeloma fastibile was used as the outgroup species. Bootstrap test included 1000 replicates and bootstrap support values $\geq 50 \%$ were indicated on the branches. Scale bar indicates the number of substitutions per site. 


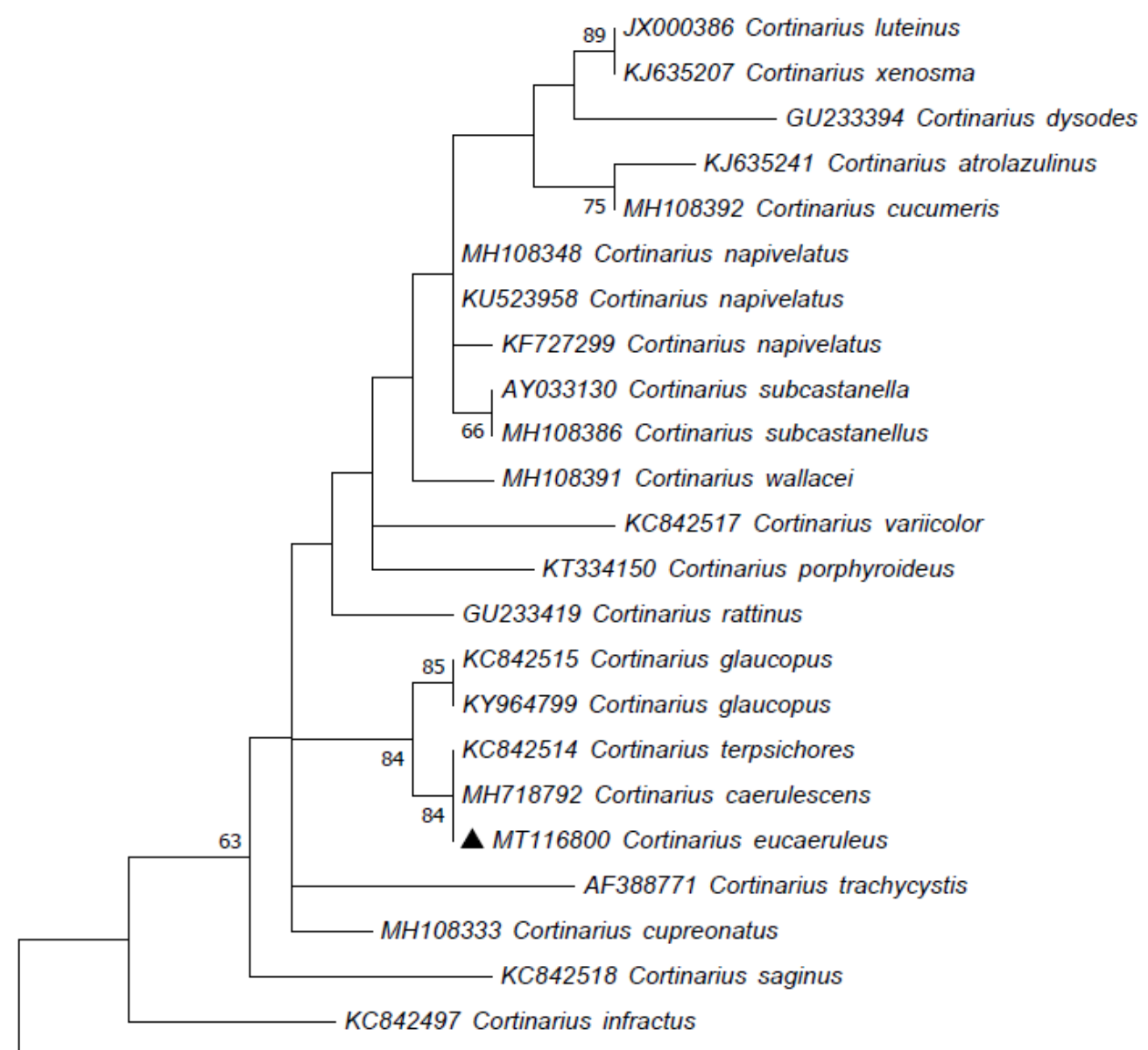

Hebeloma fastibile

0,005

Figure 3. The ML phylogenetic tree of Cortinarius based on the LSU gene region. Black triangle indicates the identified species $C$. eucaeruleus in this study. Hebeloma fastibile was used as the outgroup species. Bootstrap test included 1000 replicates and bootstrap support values $\geq 50 \%$ were indicated on the branches. Scale bar indicates the number of substitutions per site.

\section{Discussions}

Cortinarius eucaeruleus has been misinterpreted as $C$. terpsichores Melot and C. caerulescens (Schaeff.: Fr.) Fr. In previous studies (Garnica et al., 2005; Peintner et al., 2004). Recently, some collections are re-examined by Garnica et al. (2016) at the molecular level, and they were reported as $C$. eucaeruleus. Although these species are pileocarpic fungi and have similarities in pileal color, they have distinct morphological features that distinguish them from each other. The most important differences that distinguish the three species are the spore shapes and sizes (Table 1). Cortinarius caerulescens has amygdaloid basidiospores while $C$. eucaeruleus and $C$. terpsichores have ellipsoid ones. Cortinarius eucaeruleus has bigger spore size compared to that of the other two species, e.g. 8.5-10 $\times$ 5.5-6.5 $\mu \mathrm{m}$ for C. terpsichores (Knudsen and Vesterholt, 2008), and 8.8-11.5 $\times$ 5-6.5 $\mu \mathrm{m}$ for $C$. caerulescens (Breitenbach and Kränzlin, 2000). Their spore ornamentations (verrucose structures) also differ from each other. The verrucose structure in C. eucaeruleus is strong while it is thin and densely verrucose in $C$. terpsichores, and weak to moderate verrucose in $C$. caerulescens. When their ecological preferences are compared (Table 1), $C$. eucaeruleus is generally found with Quercus, Carpinus, Tilia and Corylus, while C. terpsichores is associated with Pinus, and C. caerulescens with Fagus.
The molecular phylogenetic analysis supports a distinct clade including C. eucaeruleus with high bootstrap support. Based on the ITS tree, our specimen clustered in a distinct clade with other C. eucaeruleus species, strongly suggesting that it is $C$. eucaeruleus. The results from our phylogeny are also in congruent with the results shown in Garnica et al. (2016). Cortinarius caerulescens from Türkiye (Kalmer et al., 2019) and C. terpsichores from Italy (Osmundson et al., 2013) were also positioned in the same cluster with C. eucaeruleus. In Osmundson et al. (2013), the phylogeny Included $C$. terpsichores sequence from Italy but did not include any C. eucaeruleus or $C$. caerulescens sequences for comparison. Thus, this study could not distinguish $C$. terpsichores from $C$. eucaeruleus and $C$. caerulescens at the molecular level. Interestingly, a study by Kalmer et al. (2019) showed an ITS phylogeny which clustered $C$. caerulescens from Türkiye within the clade of C. terpsichores. They did 7 not include $C$. eucaeruleus sequences in their molecular analysis. Thus, a relationship between $C$. caerulescens and $C$. eucaeruleus species was absent and should be addressed with further molecular studies. However, our detailed morphological description and molecular phylogeny analyses clearly indicate that $C$. eucaeruleus from Türkiye is different from $C$. terpsichores and $C$. caerulescens from other collections, which were 
Table 1. Comparison of macroscopic and microscopic features of C. eucaeruleus, C. terpsichores and C. caerulescens.

\begin{tabular}{|c|c|c|c|}
\hline Feature & C. eucaeruleus & C. terpsichores & C. caerulescens \\
\hline Pileus & $\begin{array}{l}40-110 \mathrm{~mm} \text {, strongly saturated violet; } \\
\text { later fading to gray-brown from the } \\
\text { centre; at margin darker violet. }\end{array}$ & $\begin{array}{l}40-90 \mathrm{~mm} \text {, at margin with light } \\
\text { blue colours, at centre ochraceous } \\
\text { yellow. }\end{array}$ & $\begin{array}{l}50-120 \mathrm{~mm} \text {, blue-violet, later } \\
\text { discolouring from the centre to } \\
\text { ochraceous buff, sometimes eventually } \\
\text { entirely pale ochre. }\end{array}$ \\
\hline Stipe & $\begin{array}{l}40-80 \times 10-20 \mathrm{~mm} \text {; with a marginate } \\
\text { bulb, pale bluish white, soon white, } \\
\text { yellowish when old. }\end{array}$ & $\begin{array}{l}40-80 \times 8-15 \mathrm{~mm} \text {, with a marginate } \\
\text { bulb, pale blue, strongest towards } \\
\text { base. }\end{array}$ & $\begin{array}{l}40-70 \times 10-20 \mathrm{~mm} \text {, cylindrical, base } \\
\text { with a marginate bulb, gray-violet and } \\
\text { longitudinally fibrillose when young, } \\
\text { later glabrescent. }\end{array}$ \\
\hline Flesh & $\begin{array}{l}\text { white to grayish white with a violet in } \\
\text { cap, violaceous to violaceous gray, } \\
\text { slightly flavescent in stipe-base. }\end{array}$ & $\begin{array}{l}\text { flesh grayish, becoming yellowish } \\
\text { in bulb }\end{array}$ & light blue \\
\hline Lamellae & $\begin{array}{l}\text { violaceous when young, becoming } \\
\text { violaceous gray }\end{array}$ & $\begin{array}{l}\text { gills grayish to slightly violaceous } \\
\text { gray }\end{array}$ & $\begin{array}{l}\text { blue-violet when young, later gray- } \\
\text { violet to ocher-brown. }\end{array}$ \\
\hline Spores & $\begin{array}{l}9-12.5 \times 5.5-7 \mu \mathrm{m} ; \\
\text { amygdaloid, } \quad \text { rather } \\
\text { verrucose. }\end{array}$ & $\begin{array}{l}8-10 \times 5.5-6.5 \mu \mathrm{m} \text {; ellipsoid, finely } \\
\text { and densely verrucose. }\end{array}$ & $\begin{array}{l}8.8-11.5 \times 5-6.5 \mu \mathrm{m}, \text { amygdaliform, } \\
\text { weakly to moderately verrucose. }\end{array}$ \\
\hline $\begin{array}{l}\text { Reactions } \\
\text { with } \mathrm{NaOH}\end{array}$ & yellowish in flesh & absent, sometimes yellowish & on the pileal cuticle and flesh ocher. \\
\hline Ecology & $\begin{array}{l}\text { with Quercus, Carpinus, Tilia and } \\
\text { Corylus, rarely with Fagus, on } \\
\text { calcareous soil. }\end{array}$ & $\begin{array}{l}\text { on calcareous soil, with Pinus and } \\
\text { with broad leaf forest (primarily } \\
\text { Fagus) }\end{array}$ & $\begin{array}{l}\text { on heavy calcareous soils under } \\
\text { broadleaved trees, with primarily Fagus }\end{array}$ \\
\hline
\end{tabular}

recently revised by Garnica et al. (2016) through a largescale DNA barcoding analysis. It is obvious that both micro-macro morphological and molecular analysis are needed to clarify the systematic position of many species in the subg. Phlegmacium. Further molecular studies including many other species of this subgenus from different geographic localities are urgently needed to have a reliable discrimination of Cortinarius species and understand their relationship in taxonomic studies.

\section{Conclusion}

Although the use of morphological and chemical characters can create consistent taxonomies for various groups, it is difficult to diagnose Cortinarius species due to the species richness, similar morphological characters and common ecological preferences. Due to difficulties in correct identification of Cortinarius species, the diagnosis and classification on these species should be supported by marker DNA sequences. Current studies now focus on both morphological ad molecular data for accurate species delimitation and nomenclature of the Cortinarius species. In this study, a phylogenetic relationship based on ITS dataset resulted in a reliable identification of the studied sample as $C$. eucaeruleus. While $C$. eucaeruleus, $C$. terpsichores and $C$. caerulescens share high sequence identity, our morphological results clearly indicate distinct morphological properties that separates $C$. eucaeruleus from the other two species. This study provides the first molecular and morphological identification of $C$. eucaeruleus from Türkiye. Molecular and morphological contributions from different geographic locations are necessary to understand the distribution and possible genetic and phenetic variations among the species of Cortinarius for an accurate taxonomic classification.

\section{Conflict of Interest}

Authors have declared no conflict of interest.

\section{Authors' Contributions}

The authors contributed equally.

\section{Acknowledgements}

This study was supported by Tokat Gaziosmanpaşa University Scientific Research Project Foundation (BAP project No: 2019/87).

\section{References}

Bas C (1969). Morphology and subdivision of Amanita and a monograph of its section Lepidella. Persoonia 5: 285-579.

Brandrud TE, Schmidt-Stohn G, Liimatainen K, Niskanen T, Frøslev TG, Soop K, Bojantchev D, Kytövuori I, Jeppesen TS, Bellù F, Saar G, Oertel B, Ali T, Thines M, Dima B (2018). Cortinarius sect. Riederi: taxonomy and phylogeny of the new section with European and North American distribution. Mycological Progress 17: 1323-1354.

Breitenbach J, Kränzlin F (2000). Fungi of Switzerland. Vol: 5, Agarics Part 3. Luzern: Verlag Mykologia.

CABI (2021). https://www.cabi.org/ [accessed 10 December 2021].

Garnica S, Weiß M, Oertel B, Ammirati J, Oberwinkler F (2003). Phylogenetic relationships of European Phlegmacium species (Cortinarius, Agaricales). Mycologia 95: 1155-1170.

Garnica S, Weiß M, Oertel B, Oberwinkler F (2005). A framework for a phylogenetic classification in the genus Cortinarius (Basidiomycota, Agaricales) derived from morphological and molecular data. Canadian Journal of Botany 83: 1457-1477.

Garnica S, Schön ME, Abarenkov K, Riess K, Liimatainen K, Niskanen T, Dima B, Soop K, Frøslev TG, Jeppesen TS, Peintner U, Kuhnert-Finkernagel R, Brandrud TE, Saar G, Oertel B, Ammirati JJ (2016). Determining threshold values for barcoding 
fungi: lessons from Cortinarius (Basidiomycota), a highly diverse and widespread ectomycorrhizal genus. FEMS Microbiology Ecology 92(4): 1-16.

Henry R (1989). Novitates - Validations, combinaisons et typifications. Documents Mycologiques 20: 68-70.

Høiland K, Holst-Jensen A (2000). Cortinarius phylogeny and possible taxonomic implications of ITS rDNA sequences. Mycologia 92: 694-710.

Index Fungorum (2021). http://www.indexfungorum.org/Names/Names.asp. [accessed 10 December 2021].

Kalmer A, Acar İ, Dizkırıcı Tekpınar A (2019). Phylogenetic and Taxonomic Studies on Cortinarius caerulescens (Schaeff.) Fr. a New Record for Turkish Mycota. The Journal of Fungus 10: 8-16.

Index Fungorum (2021). Available from: http://www.indexfungorum.org/ [accessed 10 December 2021].

Kirk PM, Cannon PF, Minter DW, Stalpers JA (2008). Dictionary of the fungi. 10th ed. Wallingford: CAB International.

Knudsen H, Vesterholt J (2008). Funga Nordica, vol 2, 2nd edition. Copenhagen: Nordsvamp.

Kumar S, Stecher G, Tamura K (2016). MEGA7: molecular evolutionary genetics analysis version 7.0 for bigger datasets. Molecular Biology and Evolution 33: 1870-1874.

Larkin MA, Blackshields G, Brown NP, Chenna R, McGettigan PA, McWilliam H, Valentin F, Wallace IM, Wilm A, Lopez R, Thompson JD, Gibson TJ, Higgins DG (2007). Clustal W and Clustal X version 2.0. Bioinformatics 23: 2947-2948.

Liimatainen K, Niskanen T, Dima B, Kytövuori I, Ammirati JF, Frøslev TG (2014). The largest type study of Agaricales species to date: bringing identification and nomenclature of Phlegmacium (Cortinarius) into the DNA era. Persoonia 33: 98-140.

Moser M (1983). Keys to Agarics and Boleti. Stuttgart: Gustav Fischer Verlag.

Moser M, Horak E (1975). Cortinarius Fr. und nahe verwandte Gattungen in Südamerika. Beihefte zur Nova Hedwigia 52: 1-628.

Muñoz Sánchez JA (2018). Sociedad Micológica Barakaldo. Available from: https://micologica-barakaldo.org/cortinariuseucaeruleus/ [accessed 10 December 2021]

MycoBank (2021). Fungal Databases, Nomenclature and Species Banks. Available from: http://www.mycobank.org/ [accessed 10 December 2021].

Osmundson TW, Robert VA, Schoch CL, Baker LJ, Smith A, Robich G, Garbelotto MM (2013). Filling gaps in biodiversity knowledge for macrofungi: contributions and assessment of an herbarium collection DNA barcode sequencing project. PloS ONE 8: e62419.

Peintner U, Horak E, Moser MM, Vilgalys R (2002). Phylogeny of Rozites, Cuphocybe and Rapacea inferred from ITS and LSU rDNA sequences. Mycologia 94: 620-629.

Peintner U, Moncalvo JM, Vilgalys R (2004). Toward a better understanding of the infrageneric relationships in Cortinarius (Agaricales, Basidiomycota). Mycologia 96: 1042-1058.

Sesli E, Asan A, Selçuk F (eds.) Abacı Günyar Ö, Akata I, Akgül H, Aktaş S, Alkan S, Allı H, Aydoğdu H, Berikten D, Demirel K, Demirel R, Doğan HH, Erdoğdu M, Ergül C, Eroğlu G, Giray G, Halikî Uztan A, Kabaktepe Ş, Kadaifçiler D, Kalyoncu F, Karaltı I, Kaşık G, Kaya A, Keleş A, Kırbağ S, Kıvanç M, Ocak İ, Ökten S, Özkale E, Öztürk C, Sevindik M, Şen B, Şen I, Türkekul, İ, Ulukapı M, Uzun Ya, Uzun Yu, Yoltaş A 2020. The Checklist of Fungi of Turkey, Ali Nihat Gökyiğit Vakfı Yayını, İstanbul.

Ślusarczyk T, Gryc M, Wantoch-Rekowski M (2015). New locations of webcap fungi Cortinarius in Poland. Przegląd Przyrodniczy 26: 3-21.

Soop K (2014). Cortinarius in Sweden I + II. 14. edition. Sweden: Editions scientrix.

Soop K, Dima B, Cooper JA, Park D, Oertel B (2019). A phylogenetic approach to a global supraspecific taxonomy of Cortinarius (Agaricales) with an emphasis on the southern mycota. Persoonia 42: 261-290.

Tamura K, Nei M (1993). Estimation of the number of nucleotide substitutions in the control region of mitochondrial DNA in humans and chimpanzees. Molecular Biology and Evolution 10: 512-526.

Tanchaud P (2020a). Available from: https://www.mycocharentes.fr/pdf1/8\%202103\%201 \%20.pdf [accessed 10 December 2021].

Tanchaud P (2020b). Available from: https://www.mycocharentes.fr/pdf1/2703.pdf [accessed 10 December 2021].

Tortelli M (2011). Cortinarius moenne-locozii, a new British record. Field Mycology 12: 122-123.

Vilgalys R, Hester M (1990). Rapid genetic identification and mapping of enzymatically amplified ribosomal DNA from several Cryptococcus species. Journal of Bacteriology 172: 4238-4246.

White TJ, Bruns T, Lee S, Taylor J (1990). Amplification and direct sequencing of fungal ribosomal RNA genes for phylogenetics. In: Innis, M.A., Gelfand, D.H., Sninsky, J.J. \& White, T.J. (Eds.) PCR protocols: A Guide to Methods and Applications. New York: Academic Press. pp. 315-322. 